known from very ancient times, when it formed an independent kingdom. The origin of the great peak of Mount Auckland, which renders the island so conspicuous, is thus given by the inhabitants (we quote from Mr. Griffis): "Clouds and fogs covered the sea, and the earth trembled with a noise of thunder for seven days and seven nights. Finally, the waves opened, and there emerged a mountain more than 1000 feet high, and forty $r i$ in circumference. It had neither plants nor trees upon it, and clouds of smoke, widely spread out, covered its summit, which appeared to be composed chiefly of sulphur." The fullest recent account which we possess is one published by a gentleman who visited the place with the French Consul in Shanghai in 1851 , to seek for the crew of a vessel, the Narwhal, believed to have been wrecked there. The story of the visit was published at the time in an English journal printed in China. The inhabitants are Coreans of the ordinary type; iron appears to abound on the southern coast, and there were ample evidences of much comfort and even wealth among the islanders. Christianity is said to have reached Quelpart through a Corean, who made his way through North China to Hongkong, where he was taught by the missionaries, and who then made his way back to the island.

THE geographical subject proposed this year by the French Academy of Inscriptions for the Prix Bordin is "A Critical Examination of the Geography of Strabo." According to the terms laid down by the Academy, competitors are (I) to give the history of the text of the work ; (2) to characterise the language of Strabo with reference to that of contemporary Greek writers, such as Diodorus Siculus and Dionysius of Halicarnassus ; (3) to distinguish the information collected by direct observation of places and that drawn by him from his predecessors ; $(4)$ to express definite conclusions on his critical method in using various documents. The papers should be in the hands of the Secretary of the Institute not later than December 3I, 1886.

THE Hungarian Society of Geography is engaged just now in organising a Magyar expedition for the exploration of the regions about the Urals, and principally of the Baskir country, where the Uralo-Altaic peoples are disappearing. The Society regards it as essential to study tribes which will soon be only a more or less confused recollection. The exploration is to be anthropological, ethnographical, and archæological.

THE Director of the Museum of Ethnography in Paris has just received from the Minister of Public Instruction a frasment of the planking of the canoe in which MM. Crévaux, Bellet, and Ringel were ascending the river when they were murdered on the Tejo-Picolmayo by the Tobas Indians. The Minister sent at the same time a collection of ethnographical water-colour drawings made by Ringel and annotated by Crévaux. These were recovered by M. Bueno, and sent to the French Legation at Rio de Janeiro.

IN the Bollettino of the Italian Geographical Society for March an attempt is made to cletermine the limits of the new "Kingdom of the Congo," as recognised by the late Berlin Conference, and modified by the treaty concluded between the African International Association, and Portugal on February 14. The territory as thus determined would be limited on the west by the Atlantic seaboard from Banana to Yabé $\left(5^{\circ} 45^{\prime} \mathrm{S}\right.$. 1at.), then by the parallel of Yabé to the meridian of Ponta da Lenha; then by this meridian northward to the Chiloango; then by the left bank of this river to its source, and beyond that point by a curved line to the Ntombo-Macata Falls on the Congo, leaving to the French the station of Mboco, but reserving Mucumbi and Manianga; lastly, from the Ntombo-Macata Falls the Congo itself to its confluence with the Bumba beyond the equator, where the boundary running north-west remains still to be determined. The southern frontier follows the Congo from Banana to a point a little above Nokki, the north bank remaining to the Association, the south to Portugal; then from near Nokki the parallel of this place as far as the river Kwango; then this river to about $9^{\circ} \mathrm{S}$. lat, and thence a diagonal line across the continent to Lake Bangweolo. Eastwards the boundary coincides with the west coasts of Lakes Bangweolo, Tanganyika, Muta Nzighé, and Albert Nyanza. On the north the frontier will follow the line of water-parting to be hereafter determined between the Congo, Nile, Shari, and Benué (Niger) river basins. Within these limits the new State will have an approximate area of about $I, 000,000$ square miles and a population of probably 40,000,000, mostly of Bantu speech and Negro or Negroid stock.

THE same number of the Bollettino publishes a letter from Count Giacomo di Brazza, dated Brazzaville, October 22, I884, in which the writer complains that his efforts to complete the triangulation of Stanley Pool were frustrated by the officer of the African Association, a certain Captain S., in charge of the left bank of the pool. To complete the work it was necessary to cross over to that side of the Congo; but the permission to do so was refused by the official in consequence of instructions issued by Colonel de Winton, "that all were to remain on their own side."

\section{ON THE SALINITY OF THE WATER IN THE FIRTH OF FORTH}

$\mathrm{I}^{\mathrm{T}}$ is the purpose of this paper to state the methods employed for examining the salinity and alkalinity of estuary water at the Scottish Marine Station at Granton, and to describe and record six months' observations of the water of the River and Firth of Forth up to December $3 \pi, 1884$.

(I) Collection of Wattr Samples. - To collect a sample of surface-water from a small boat it is sufficient to wash out the bottle with the water, and then hold it a few inches under the surface until it fills. The temperature of the water is taken by means of an ordinary thermometer in a copper case. On board a larger vessel the same thing may be done, the bottle being attached to a sounding-line and lowered over the side, or, with. out stopping the vessel, by means of a clean bucket, care being taken to draw the sample forward of the ejection-pipe of the condenser. When brought on board a thermometer is immersed for a minute, and the temperature noted. The water is then bottled, tied down, and labelled.

The water-bottle employed for obtaining samples from any depth beneath the surface consists of a brass basal disk support. ing three radiating sheets of brass surmounted by a brass dome, on the top of which there is a ring for the line. The basal plate has an india-rubber ring fixed upon it, and its under surface has two rings for attaching the lead, and a stopcock for running off the water. There is also a brass cylinder, the edge of which rests upon the india-rubber ring when the instrument is closed.

On board the Medusa, the steam-yacht of the Marine Station, the water-botile is attached to the sounding-line, which is wound on a drum worked by a small deck-engine. It has a $7-1 \mathrm{lb}$. lead attached to it, the stopcock is closed and a little plug screwed in to prevent the entrance of mud should it strike the bottom. It is then lowered, the slip-cylinder being held in the hanc. When the desired depth is reached the slip is let go; it crashes down on the frame and is guided by the brass strips on to the india-rubber ring, on which it presses, and so firmly incloses a sample of water. It has been found necessary to let down one or two cylindrical weights, slipping on the line, after the slip has struck the body, in order to press it firmly down. Repeated trial and continuous use have shown this manner of watercollecting to be satisfactory.

The bottles used for preserving the samples are glass-stoppered, blue glass half-Winchesters, which hold about $1 \cdot 5$ litres. They are packed in boxes, fifteen in each, so as to be carried easily and safely. Kach bottle is labelled as it is put aside, with particulars of the date, hour, and temperature.

The temperature below the surface is ascertained by means of the Negretti and Zambra thermometer in the Scottish frame, which was described to this Society in July, 1884 (Proceedings, vol. xii. p. 927).

When each sample of water is taken, the following observations are made and recorded :- Date; hour ; position by bearings; depth of water ${ }^{2}$ depth from which sample was taken temperature of the water at that depth; temperature of the air ; nature of the weather, wind, and state of sea; state of tide; colour and transparency of the water. ${ }^{2}$

The colotr of the water is observed by sinking a disk of iron, painted white, to the depth of a few feet or fathoms, according to circumstances, and noting its colour. The transparency may be very roughly measured by observing the distance to which the disk remain visible.

It is important that the actual notes of all observations be

I Abstract of a paper read at the meeting of the Royal Society of Edinburgh, January 5 , 1885, by Fugh Rotiert Mill. B.Sc., F.C.S., Chemist to the Scottish Marine Station, Granton, Edinburgh. 
preserved for future reference should uncertainty arise regarding them. There are difficulties in cloing this, for it is not easy on a sinall vessel, when there is any sea on, to keep an ordinary note-book from getting wet. It is most convenient to use cards with memoranda of the observations to be made printed on them, which are kept in a small leather case, and when cach card is used, it may be slipper beneath the others, as is done in a date-case. 'The cards can he conveniently kept in boxes, and may be rcadily and rapidly referred to at any time.

2. Detormination of the density. - The density of the samples of water collected in the Firth is determined by means of a very delicate hyrirometer of the form used on board the Challenger. The hydrometer is made of glass, the tubes for borly and stem having been very carefully selected to ensure uviformity of diameter. The instrument has a body of about $5 \mathrm{~cm}$. diameter and $12 \mathrm{~cm}$. long; the stem is nearly the same length, and has a diameter of $3 \mathrm{~mm}$. The process of making and calibrating the hydrometer has been described in great detail by Mr. Buchanan in his Challenger report on the specific gravity of ocean water ("Challenger Rep. Phys. Chem.," vol. i. pt. ii. pp. I-4.)

The hydrometer which has been used at the Marine Station is provided with seven movable weights, which can be attached to the top of the instrument, and so increase the weight of the hydrometer from $150^{\circ} 1478$ grms. to 155.8390 grms. through thirty-six graclations. The volume of the body and bulb of the instrument is $150^{\circ} 2070 \mathrm{cc}$. at $0^{\circ} \cdot 3$, and its coefficient of expansion is known; the volume of the $100 \mathrm{~mm}$. into which the stem is divided is $0.85 \mathrm{cc}$., and as it is assumed to be uniform, the volume of each millimetre of the stem is talken as 0.0085 .

The density of each water-sample was taken twice, by first wing a weight that clid not immerse more than the lower third of the stem, then adding another to immerse at least two-thirds. A table siving the volume of the hydromeicr at every tenth of a degree Centigrade from $0^{\circ}$ to $25^{\circ}$ has been drawn up, and from this table the volume of the body at the observed temperature is taken; the volume of the stem immerser is got from another table, which gives the value for each half millimetre from o to 100. These added together give the total immerserl volume, and, the weight being taken from another table and divided by this volume, gives the density at the observed temperature. The mean of the two densities is taken, and reduced from the mean of the two corrected observed temperatures to $15^{\circ}, 56 \mathrm{C}$. by means of Dittmar's table ("Chall. Rep. Phys. Chem.," vol, i. part $\mathbf{i}$, p. 70 ).

Advantage was taken of the double determination of each clensity and of a number of separate experiments to form an idea of the probable error of an individual determination. The result showed that the probable uncertainty is not more than

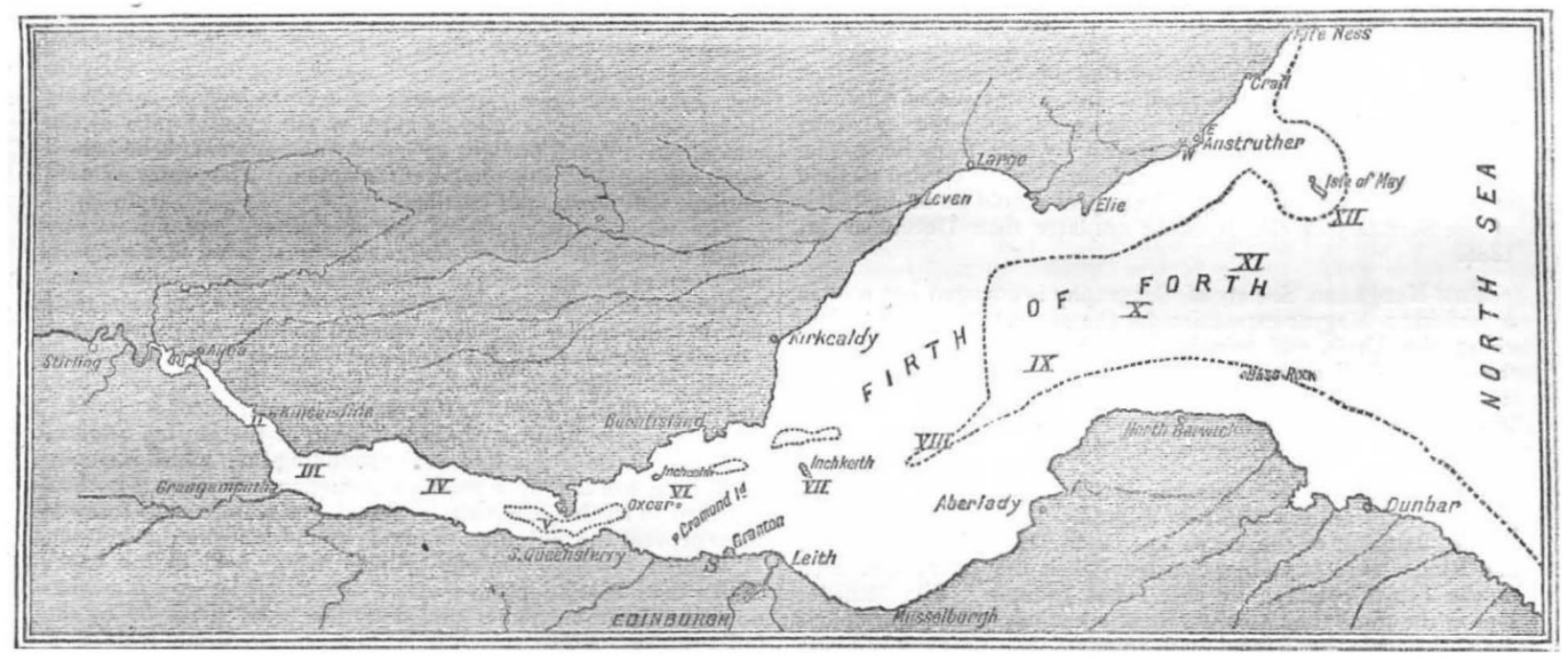

MaP of PART OF THE River AND of THE FirTil OF ForTh, (20-fathom line:

...).

Stations for water samples:-I. Alloa; II. Kincardine; III. Hen and Chickens Buoy (near Grangcmouth); IV, Porrowstounness; V. Off Queensferry (near Inchgarvie); VI. Oxcar Beacon (near Inchcolm); VII. Herwit Buoy (near Inchkeith); VIII., IX., X., XI. five miles apart: XII. Isle of May; S, Scottish Marine Station.

0.00005 , taking pure water as 1.00000 , aml that consequently, in considring the relative densities of the water in the lirth, the fourth decimal place is certain.

'The amount of total halogen was determined by Mohr's volumetric method, but, as the probable error was so great as to render the second decimal place in the per milleage uncertain, no reliance can be placed on the results. The largeness of the uncertainty is due, in part at lea-t, to the disadvantageous position in which the determinations were made $\rightarrow$ floating laboratory where the atmosphere was always more or less laden with saline particles.

The alkalinity was determined by Tornoe's method with standard solutions of hychochloric acid and of potash.

The quantity reprosented by an alkalinity is very small, although the number used to express it is large. An alkalinity of 50 means that in a litre-say 1026 grammes-there is 0.05 gramme of carbonic acid as calcium carbonate; that is, a percentage of 0.00487 , which, from the inaccuracy of the deter. minations, might vary from 0.00498 to $0^{\circ} 00476$.

\section{Notes of Previous Wurk on Fisluavy Water}

In 1816 Dr. John Murray read a paper to this Society on the composition of sca-water, the samples which he analysed being taken from the Firth of Forth neas Leith. The paper (Trans. R.S.F. for 1816 ) contains results of great theoretical value, which were instrumental in modifying the theory of the existence of salts of different bases and acids in solution, and which altogether changed the mode of analysis of sea and mineral watcrs. Attention was given more particularly to the solid constituents, and no observations seem to lave been made by Dr. Murray on the variations in salinity at different parts of the Firth.

Dr. John Davy published a paper (Ed. Neze Piail. Fourn. xxxvi. p, I) in 1843 , on "The Temperature and Specific Gravity of the Water of the Firth of Furth." IIc examined the temperature and clensity of the water at the end of Leith pier on cight occasions at intervils of about a month. It was Davy's intention to continue the monthly observations for a number of years, but, as he had to leave Edinburgh, they were stopped. Since no particnlars as to how the densities were determined wcre given, it is impossible to compare them with others observed at a later date.

Dr. Stevenson Macadam investigated the salinity of the Firth of Clyde in 1855 (Brit. Assoc. Reports, 1855, ii. 64). He observed the specific gravity at more than fifty places, and determined the total solids and chlorine in each. In subsequent investigations he examined the Firths of Cromarty and Inverness. The results are recorded in the Procedings of this Society for I866 (Froc, Roy. Soc. Ed., p. 5).

Prof. Kyle, of Buenos Ayres, marle some observations in 
r874 on the River Plate, in the same way as Dr. Macadam on the Clyde. Mr. F. Newman has kindly supplied a translation of Kyle's Spanish pamphlet "Algunos Datos sobre la Composicion de las Aguas del Rio de la Plata"), and a chart of the Plate, with the water-sampling stations. The results brought out by Prof. Kyle are interesting, but, like the other observers cited above, he neglects to mention whether his specific gravities are reduced to $0^{\circ}$, to $4^{\circ}$, or to $15^{\circ} 5^{\circ}$, or whether water at $0^{\circ}, 4^{\circ}$, or $15^{\circ} .56$ was taken as unity. It is therefore impossible to consider the results except as purely relative to the estuary in question, and no comparison between the different investigators can be made.

The Cattegat, Skagerrack, Baltic, and north-eastern parts of the North Sea have been made the subject of very careful and prolonged examination by various Danish and German scientific workers. Water-samples have been taken regularly for a number of years at various points aiong the coast, and from lighthouses and light-ships at considerable distances from land. The results of the examination of these samples from 1872 to 1881 are tabulated in conjunction with the meteorological conditions, especially with respect to rainfall, in a recently issued paper by the Commission in Kiel for the scientific investigation of the German seas. ${ }^{1}$ The general low densities of these waters, and the variations to which they are subject, make the conditions which obtain there not unlike those in an estuary.

While it is fully realised that it will take years of consecutive observations to thoroughly settle the relations of the fresh and salt water in an estuary, and that many conditions, such as the currents, law of the tides, and rainfall over the area drained by the principal river and its tributaries must be taken into account; it is considered expedient to state the results observed in the six months, from June to December, 1884, on the Firth of Forth. These results are purely preliminary; but as little attention has been given such matters hitherto, they may prove of interest, and may lead to suggestions for improvements in carrying on the work.

The Firth of Forth.-The River Forth rises in the valley between Ben Lomond and Ben Venue, is joined near Stirling by the Teith, and gradually merges into the Firth of Forth, the precise point where the river ends and the Firth begins being a matter which permits of difference of opinion. Probably the best plan is to view the river as ending at Queensferry, but for convenience the term "Firth of Forth" may be applied as describing the river and Firth proper from Alloa to the Isle of May, a distance of fifty-five miles. According to Keith Johnstone the area drained by the Forth is 500 square miles. Few large rivers flow into the Firth. Those of any importance are : on the north side, the Black Devon, at Clackmannan; and the Leven, at Leven : on the south side there are the Carron, at Grangemouth; the Avon, a few miles further east; the Almond, at Cramond; the Water of Leith, at Leith; the Esk, at Musselburgh; and the Tync, near Dunbar.

From Alloa to within three miles of Queensferry the depth of the water is under Io fathoms; there it increases, at first gradually, then at the Bamer Beacon abruptly, to over 30 fathoms, and close to Inchgarvie, to over 40 tathoms. This is the deepest part of the Firth, and the narrowest. The Forth Bridge is in process of construction at this point. A very strong tirle runs in the channels on each side of lnchgarvie, and the deep water is confined to a very small area. The so-fathom stream runs along the northern shore, until off Kirkcaldy, where it widens out in a funnel shape, and approaches the shore on each side. There is a short tract over Io fathoms to the south of Inchkeith, known as the Narrow Deep. Several small depressions of more than 20 fathoms occur between Queensferry and Inchkeith, and a little to the east of that island the 20-fathom area begins as a narrow stream trending northward, and spreading out off $r$ argo. The 1sle of May is connected to the mainland of Fife by a submerged plateau rising to less than 20 fathoms from the surface; and, about four miles east of the May, depths beyond 30 fathoms commence.

A line drawn from Aberlady Bay to Largo divides the Firth into two very different halves. To the west of it the slope of the bed is extremely gradual, and the depth slight; to the east of it the shore slopes down abruptly, and the bed of the Firth is, with one or two insignificant exceptions, uniformly over 20 fathoms in depth.

I Vierter Bericht-für die Jahre 1877 bis $188 \mathrm{I}$. Berlin, I884: "Periodische Schwankungen des Salzgehaltes im Oberflächenwasser in der Ostsee und Nordsee."
Observations on the Surface Salinity in the Firth.-It is assumed that the amount of total salts may be deduced from the density, as if estuary water were ocean water diluted with pure water. This cannot he exactly the case, as the salts carried down by rivers are in quite different proportion to those found in the sea, and before the processes occurring there have had time to priduce uniformity of composition-that is, where river-water pre. dominates - the proportion of salts among themselves must vary. Consequently, until exact experiments can be made on this point, the interpretation of estuary densities by ocean-water tables must be taken with reservation, and it is better to view the densities as such, without reducing them to amounts of total salts. To get a preliminary vicw of the rate of freshening, it was determined in September I 884 to make a monthly trip for collecting water samples from the entire Firth ; and on September I8 the Medusa proceeded from Inchkeith to Grangemouth for that purpose. Surface samples were talien every five miles, and bottom samples at each alternate station. Observations were made both in going and in returning. 'The intention to make the complete tour of the Firth in one day had to be relinquished, and the Inchkeith to May section was completed on the 25th. This double trip showed that the densities of the water samples decreased steadily, gradually, and uniformly from the May to Inclkeith, but that the change then became more rapid, the curve resembling a portion of a rectangular hyperbola. The second water sampling trip was on October 7 and 8 ; the water, beautifully clear and transparent, and of a deep green-blne colour at the May, became light green and less transparent about Inchkeith, and from Inchgarvie onwards it was yellow and very muddy. The results were similar to those of September. The November trip took place on the roth and $\mathbf{I} \boldsymbol{I}$ th ; the weather was fine, almost summer-like, and, in consequence of previons heavy rains, all the rivers were in flood. The effect was a marked lowering of the density of the surface water, greatest in the upper reaches of the Firth, but quite perceptible at the Isle of May, which is almost in the open sea. The effect of this "spate" was to reduce the density at Inchgarvie from its mean

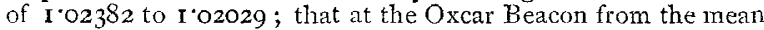
of $\mathrm{I}^{\circ} \mathrm{0} 243^{8}$ to $\mathrm{r} \cdot \mathrm{O} 2 \mathrm{O} 22$; that at Inchkeith from $\mathrm{I} \cdot 02472$ to I 02403 ; and those at Stations VIII. and IX. from I 02505 and $\mathrm{r} \cdot 025 \mathrm{I} 8$ to $\mathrm{I} \cdot 0245^{8}$ and $\mathrm{I} \cdot 02508$ respectively. The December trip did not take place till the 25 th, when my friend Mr. Ritchie was good enough to take charge of the eastern excursion. The day was fine, with a north-easterly breeze and a slight swell. On

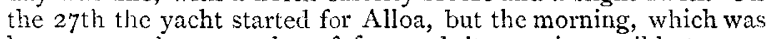
hazy, gave place to a day of fog, and it was impossible to proceed beyond Inchgarvie. The 29 th and 3 oth were also misty, and this portion of the trip had very reluctantly to be dispensed with.

The effect of the tide obscures the changes of salinity to a certain extent in these monthly cruises, but, although the data are so few, they are sufficient to show that between Inchkeith and the Isle of May - that is, in the wide and open part of the Firth-the tidal effect is relatively slight and the variations in density very gradual, though perceptible; while from Inchkeith to Alloa the tidal effect increases with every mile, and the rate of change becomes more and more rapid. The following tables (I. and II.) give the figures observed in these consecutive trips :-

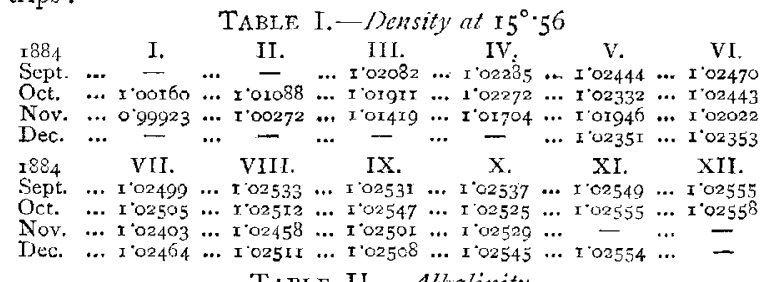

TABLE II.-Alkalinity

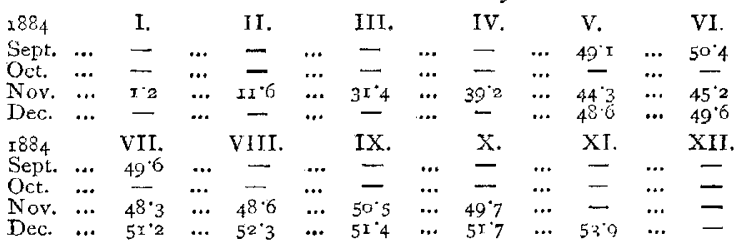

The mean of the density, \&c., at the stations going and returining is glven hers. 
The maximum, minimum, and mean of all the density observations at each station, together with the number of cases which give the mean, arc tabulated (Table III.). The temperature observations made on the monthly trips have not been alluded to here; they are intended to form a separate paper.

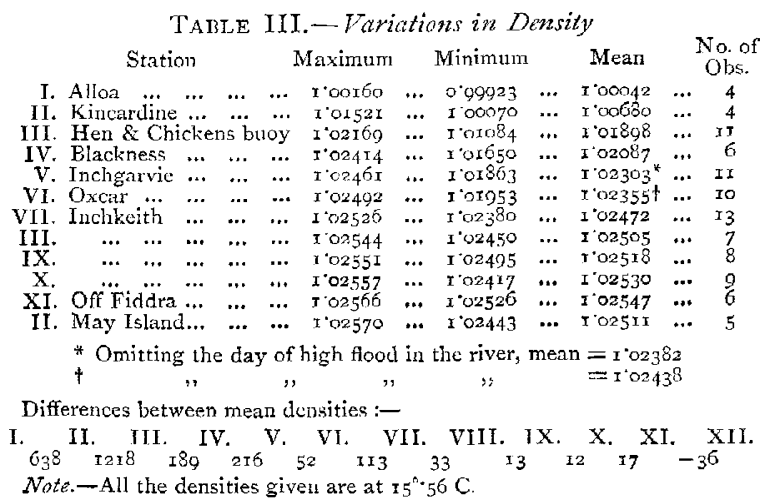

The change of temperature produces a corresponding change of the density of the water in situ, which has important bearings on convection currents, and which must also infuence the rate of mixture of sea and river water, especially as the temperature of the river water is in winter usually below that of its maximum density.

An examination of Table III. shows that for maximum and ninimum, as well as for mean observed densities, the increase is perfectly continuous until the last station is reached, when the maximum density is only probably greater than that at Station XI., the minimum is certainly less than that at Station VIII., and the mean is less than that at Station IX. It is not easy to find an explanation of this fact, for there is no river nearer than the Tyne at Junbar, and there are no springs on the Isle of May, the lighthonse keeper being compcled to get all his fresh water carried from Crail. The proximity of the Firth of Tay may possibly account for the observation.

The difference between the density of the surface-water at high and at low tide is by far the greatest in the upper reaches of the Firth, anci decreases more and more gradually. Beyond Inchkeith the differenec is little noticed, in fact the water is found to be somclimes denser at a lower state of tide. This effect may be due to currents which are not taken account of in this prcliminary investigation. The rate of change of density with the tide decreases very rapidly at first. At Kincarline the difference between high and low water is $I$ in the second place of decimals, or, calling the density of pure water 10,000 , it is 100 ; at Inchgarvie it is about 15 , at Inchkeith 4 , and beyond Inchkeith about $\mathrm{I}$; that is $\mathrm{I}$ in the fourth decimal place by ordinary notation.

The density of the surface-water was determined almost daily from August to Deccmber at the Scottish Marine Station, Granton, but the results were so variable, that dependence cannot be placed upon them as representative of the water in the Firth at that point. The density was always found to be greater at low water, and after some trouble the cause was ascertained. From the station westward for a distance of a mile and a half the shore dries at low water for from quarter to half a mile, and Cramond Island becomes a peninsula, on the west or further side of which the River Almond discharges itself. At high watcr there is from half to one fathom of water between Cramond Island and the coast, and the river, laking the shorter course, is carricd by the cbb tide along the shore, and so reduces the den ity of the water in the neighbourhood.

As there was considerable time lost in devising and tosting a suitable means of collecting samples of bottom water, the number of reliable cases for consideration is small.

It may be generally stated that the part of the Firth east of Inchkeith is the region where the difference between the density of surface and boltom water is least, and that the difference decreases steadily towards the May. Towards Alloa, on the other hand, the differences in the density between surface and bottom water are great, but they are greatly infucnced by the tide. Table IV. gives details of ninetecn comparisons between bottom and surface water.

At the IIen and Chickens Buoy, near Grangemouth, the depth is only $5 \frac{1}{9}$ fathoms, but the salinity is very much greater at the bottom than at the surface. The difference is least observed at low water, but as the flood tide sets in, it appears to increase, and then to fall off again as the elb commences. The only divergence from this rule noticed was on November II, when the rivers were all much flooded and the current very rapid. It would appear that these observations confirm the theory that sea water asccnds rivers along the bottom under the opposite current of fresh water.

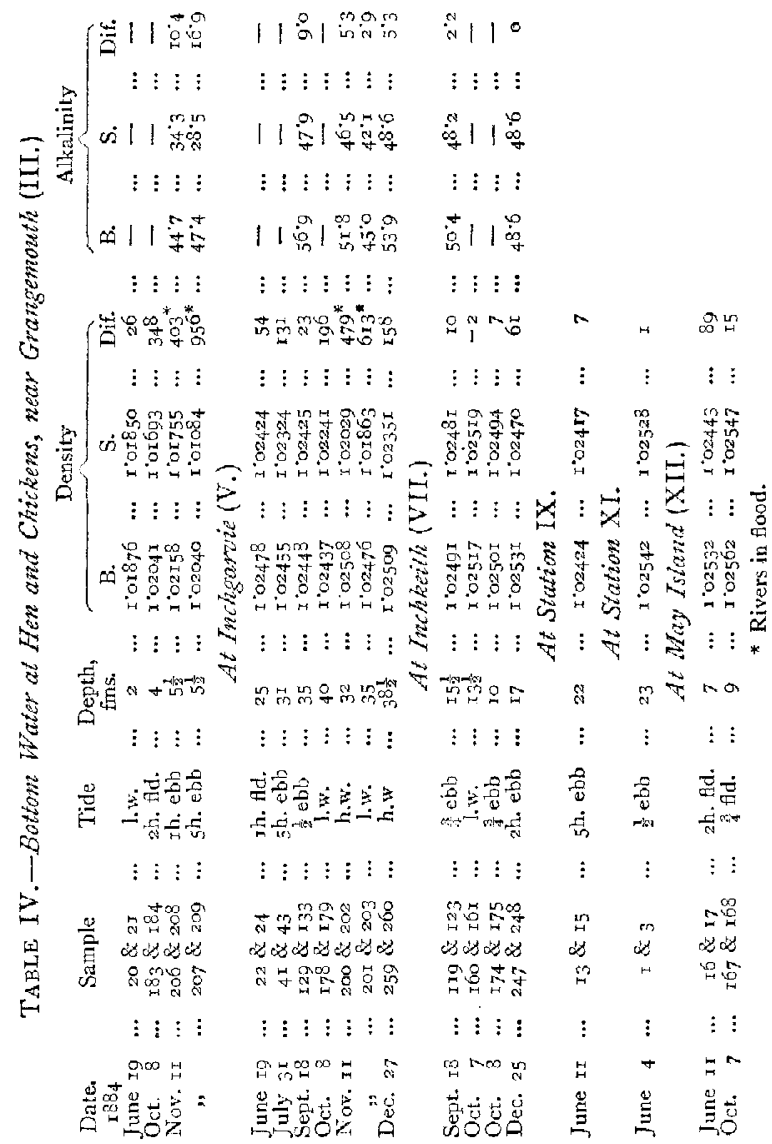

Speaking roughly, it appears that waters having an alkalinity under 40 (that is, in which there is less than $0^{\circ} 04$ grammes of carbonic acid as carbonate of lime per litre) have a density under $1 \cdot 0200$, alkalinities under 25 correspond to densities under $\mathbf{I}$ oroo. The only strikingly anomalous case is that of sample 189 , a boltom water from off Alloa, when the river was low and very dirty. The density was 100146 , the alkalinity $47^{\circ} 9$, which usually corresponds to a density of I 024 . The presence of sewage in the river might acc unt for this observation to some extent, but more probably it was due to the pre sence of particles of calciurn carbonate. With an alkalinity between 40 and 50 water has a density between $I^{\circ} 024$ and $I^{\circ} 025$ as a general rule, and when the alkalinity is over 50 the density is almost invariably over 1.025 .

On account of the absence of data for deducing the total salts of cstuary water from the density, we cannot reduce the alkalinity to percentage of total salts, and, consequently, it is impossible to form a correct idea of the difference between bottom and surface alkalinities, as this difference may be entirely duc to the different salinity of the water.

Arrangements have been made for continuing and greatly extending observations on the salinity of the Firth of Forth. Samples of water will be taken by trustworthy obscrvers at high and low water at different points on the Firth, and watersampling trips, both from Alloa to the May and across the Firth from north to south at various places, will be carried on regularly. 
Throughout this paper the density of the water is given as reduced to $15^{\circ} 56 \mathrm{C}$. $\left(60^{\circ} \mathrm{F}\right.$.). It is specific gravity at $15^{\circ} .56$ referred to pure water at $4^{\circ} \mathrm{C}$. as unity.

The water-sampling stations and the principal contour lines of depth are shown in the chart of the Firth of Forth (Fig. I).

\section{THE PEARL FISHERIES OF TAHITI}

A RECENT issue of the Fournal Officicl contains a lengthy report by M. Bouchon-Brandely, Secretary of the College of France, who was sent by the Ministry of Marine and the Colonies on a mission to Tahiti to stuly questions relating to oyster-culture there. The principal product of what M. Brandely, with "the summer isles of Eden" fresh in his mind, calls " notre belle et si poétique colonie de Tä̈ti" is mother-ofpearl. All its trade is due solely to this article, which for a century has regularly attracted vessels to the islands which compose the archipelagoes of Tuamotu, Gambier, and Tubuai. The mother of-pearl which is employed in industry, and especially in French industry, is furnished by various kinds of shells, the most estimated, variegated, and beautiful of which are those of the pearl oyster. There are two kinds of pearl oystersone, known under the name of pintadine (Meleagrina margaretifera), is found in China, India, the Red Siea, the Comoro islands, North-Eastern Australia, the Gulf of Mexico, and especially in the Tuamotu and Gambier archipelagoes; the other, more commonly called the pearl oyster (Meleagrina radiata), comes from India, the China seas, the Antilles, the Red Sea, and Northern Australia. The shell of the former is harder, more tinted, more transparent, and reaches greater dimensions than the latter. Some have been found which have measured thirty centimetres in diameter and weighed more than ten kilogrammes, while the Meleagrina radiata rarely exceeds ten centimetres at the most, and never weighs as much as $\mathrm{I} 50$ grammes. Both varieties supply pearls, those of one kind being at one time more favoured, at another time those of the other. This depends on fashion ; but, on the whole, those found in the great pintadine are more beautiful, and the colour more transparent, than those of its congener. The amount of the trade from Tahiti in pearls cannot be stated with accuracy, as there is much clandestine traffic, but $M$. Brandely puts it down approximately at 300,000 francs, England, Germany, and the United States being the chief markets for the fine pearls. The great pintadine is found in great abundance in the Tuamotu and Gambier islands. The siluation there is very favourable to them ; in the clear and limpid waters of the lagoons they have full freedom for development, and are undisturbed by storms. Mother-of-pearl is found in almost every one of the eighty islands which form the archipelagoes Tuamotu and Gambier. These belong to France, having been annexed at the same time as Tahiti and Moorea, and have a population of about 5000 people, all belonging to the Maori race. M. Brandely gives an interesting description of these little-known illands and people. The latter appear to hover always on the brink of starvation, as the islands, which are composed mainly of coral-sand, produce hardly anything of a vegetable nature. While the neighbouring Society islanders have everything without labour and in abundance, the unfortunate inhabitant of Tuamotu is forced to support existence with cocoa-nuts, almost the only fruit-trees which will grow on the sandy beach, with fish and shell-fish which are poisonous for several months of the year, and often they have to kill their dogs for want of other animal food. There are no birds, except the usual sca-birds; no quadrupeds, except those brought by man; no food resources necessary to European life, except what is brought by ships. Although the people are gentle and hospitable, they practise cannibalism, and $M$. Brandely suggests that it is pitiless hunger alone which has driven them into this horrible custom. These miserable people are the chief pearl-divers of the Pacific ; indeed it is their only industry, and women and even children take part in it. There is at Anaa, says the writer, a woman who will go down twenty-five fathoms, and remain under water for three minutes. Nor was she an exception. The dangers of the work are great, for the depths of the lagoons are infested by sharks, against which the divers, being unable to escape, are forced to wage battle, in which life is the stake. No year passes without some disaster from sharks, and when one happens all the divers are seized with terror, and the fishing is stopped for a time. But gradually the imperious wants of life drive them back to the sea again, for mother-of-pearl is the current coin of the Tuamotu. With it he buys the rags which cover him, the little bread and flour which complete his food, and alcohol, "that fatal present of civilisation," for which he exhibits a pronounced passion. 'Twenty or thirty years ago the trade in mother-of-pearl in the Tuamotu archipelago was very profitable for those engaged in it. For a valueless piece of cloth, a few handfuls of flour, or some rum, the trader got half a ton of mother-of-pearl worth one or two thousand francs, or even fine pearls of which the natives did not know the value. The archipelagoes were frequented by vessels of all nationalities; mother-of-pearl was abundant, and pearls were less rare than they are now. The number of trading-ships increased; there was competition amongst them, and consequently a higher price to the natives, who fished to meet the new demand with improvident ardour. The consequence is that the lagoons are less productive, and that even the most fertile give manifest signs of exhaustion. The prospect of having the inhabitants of Tuamotu thrown on its hands in a state of helpless destitution, as well as of the disappearance of the principal article of the trade of Tahiti, and an important source of revenue to the colony, alarmed the Colonial adiministration, and the Ministry of Marine and the Colonies in Paris. Accordingly, M. Brandely was selected to study the whole subject on the spot. The points to which he was instructed to direct especial attention were these: (I) The actual state of the lagoons which produce oysters; are they beginning to be impoverished, and if so what is the cause, and what the remedy? (2) Would it be possible to create at Tuamotu, Gambier, Tahiti, and Moorea, for the cultivation of mother-of-pearl, an industry analogous to that existing in France for edible oysters? Would it be possible by this means to supply the natives of Tuamotu with continuous, fixed, remunerative labour which would render them independent, and remove them from the shameless cupidity of the traders? Could they not be spared the hardships and dangers resulting from the continued practice of diving, and be turned to more fixed sedentary modes of life, by which they might be raised gradually in the social scale? (3) Should the pearl fishing in the archipelagoes be regulated, and, if so, what should be the bases of such regulations? It was on the mixed economical and philanthropic mission here indicated that M. Brandely went to Tahiti in February last. The statistics did not show any decline in the production of mother-of-pearl, but a careful study on the spot showed that this was due to the great amount of the clandestine traffic, and that the lagoons were growing less productive day by day, that beautiful mother-of-pearl was becoming rarer, and in order now a-days to get oysters of a marketable size, the divers are forced to go to ever greater depths. M. Brandely recommends prompt and vigorous measures be taken at once, as the lagoons of 'Tuamotu will soon be ruined for ever. The partial steps already adopted have becn useless. The total prohibition of fishing in some of the islands for several years has failed, because it has been found that the pintadine is hermaphrodite, and not, as formerly was believed, unisexual. The cause of the impoverishment of the lagoons is excessive fishing, and nothing else. $\mathrm{He}$ thinks that it is possible to create in Tuamotu, Gambier, Tahiti, and Moorea a rational and methodical cultivation of mother-of-pearl oysters, analogous to that existing with regard to edible oysters on the French coasts, and to constitute for the profit of the colony an industrial monopoly which no other country can dispute, for nowhere else can such favourable conditions be met with.

\section{SOCIETIES AND ACADEMIES LONDON}

Royal Society, March 26.- "On the Peculiar B.haviour of Glow Lamps when raised to High Incandescence." By W. H. Preece, F.R.S.

The experiments described had for their object the investigation of a phenomeion observed by Mr. Edison, who brought it to the author's notice last autumn. Between the limbs of an incandescent filament of a glow-lamp a thin, narrow platinum plate being fixcd with an independent wire connection, and a sensitive galvanometer being placed in circuit between the filament and the platinum, a derived current is observed to pass through the galvanometer and through the rarefied space at the bottom of the $\operatorname{limb}$ when the main current is increased to a certain strength and the filament reaches a certain degree of incandescence, the strength of the derived current increasing with the increased brilliancy of the glowing filament. In the author's investigations Mr. Edison had made other lamps, in 